Received 22 January 2021 Accepted 25 January 2021

Link to DOI:

10.25220/WNJ.V04.i2.0004

Journal Website: www.worldnutrijournal.org

\section{Protein and iron intake adequacy among high school girls in Depok, Indonesia}

\author{
Meirina Khoirunnisa ${ }^{1,3}$, Yoga Devaera ${ }^{2}$, Umi Fahmida ${ }^{3}$, Fiastuti Witjaksono ${ }^{1}$, Erfi Prafiantini ${ }^{1}$ \\ 1. Department of Nutrition, Faculty of Medicine, Universitas Indonesia-Dr. Cipto Mangunkusumo \\ General Hospital, Jakarta, Indonesia \\ 2. Department of Pediatrics, Faculty of Medicine, Universitas Indonesia, Dr. Cipto \\ Mangunkusumo General Hospital, Jakarta-Indonesia \\ 3. Southeast Asian Ministers of Education Organization Regional Center for Food and Nutrition \\ (SEAMEO-RECFON)/Pusat Kajian Gizi Regional (PKGR), Universitas Indonesia, Central Jakarta, \\ Indonesia
}

\begin{abstract}
Introduction: Iron deficiency anemia is the most common type of anemia among adolescent girls. The prevalence of anemia among pregnant women increased from 2013 to 2018, and females age 15-24 years had the highest prevalence of anemia. Therefore, knowing the baseline status of protein and iron intake - particularly animal-sourced protein as the main source of heme iron-is important to design future intervention program. Thus, this study was aimed to assess the protein and iron intake adequacy of High School girls in Depok, Indonesia.

Methods: 211 girls from Senior High School in Depok, Indonesia participated in this study. Subjects were selected using a multi-stage random sampling method. A questionnaire was administered to obtain general characteristics. Dietary intake data were obtained using a 3-day non-consecutive $24 \mathrm{hr}$ recall 1 weekend 2 weekdays interview. Anthropometric status was measured and calculated. Data were analyzed using IBM SPSS Statistics 20. Spearman's correlation (significance $p<0.05$ ) was used to determine the factors related to protein and iron intake.

Results: This population had inadequate intake of energy (97.2\%), protein $(59.7 \%)$, and iron (98.6\%). However, intake of fat was higher than recommended in $59.2 \%$ of participants. Protein and iron intake were not correlated with age, father's education, mother's education, and the number of household member.

Conclusions: This population had low energy, protein, and iron intake adequacy while $59.2 \%$ had fat intake more than recommended. There was no relationship between protein and iron intake with age, father's education, mother's education, and the number of household member. Further studies on factors related to low protein and iron intake are needed to formulate a suitable intervention program.
\end{abstract}

Keywords protein, iron, adolescent girls, recommended nutrient intake 


\section{Participant and recruitment}

\section{Introduction}

Adolescence is the period of growth spurt, a period in which the growth is faster than any period in an individual's life except during the first year. Although the rate of growth during adolescence is second to that in infancy, it is greater in duration, and therefore total nutritional requirements during puberty may be greater than during any other period in life ${ }^{1}$. Adolescent girls are particularly vulnerable to malnutrition because they need to meet the body's increased demand due to menstruation and future pregnancy ${ }^{2}$.

Iron deficiency anemia is the most common type of anemia among adolescent girls. RISKESDAS results showed that the prevalence of anemia among pregnant women increased from $37.1 \%$ in 2013 to $48.9 \%$ in 2018 . Among those pregnant in 2018, females age 15-24 years had the highest prevalence of anemia at $84.6 \%{ }^{6}$. One of the many ways to improve anemia status is by improving the iron intake and protein intake especially animal-sourced protein as the main source of heme iron ${ }^{19}$. Low protein adequacy may also result in low lean body mass, which is associated with many adverse health outcomes in the future like metabolic syndrome and low immunity ${ }^{2}$.

The adolescent period is a good opportunity to introduce health intervention to improve anemia status before pregnancy and prevent future health consequences. Therefore, it is important to know the intake of iron and protein of adolescent girls as a baseline for developing an educational intervention ${ }^{19}$. Thus, this study aimed to assess the protein and iron intake adequacy of high school girls in Depok, Indonesia

\section{Methods}

This cross-sectional study was a part of a joint study between Universitas Indonesia and RSUI for the development of healthcare in Depok City. Data collection was conducted from October until December 2018.
Subjects of this study were adolescent girls enrolled in Senior High School in Depok. The inclusion criteria were female students attending Senior High School grade 10 and 11. Those with an apparent physical disability, those with medical conditions that cause them to follow dietary protein restriction (i.e. chronic kidney disease, phenylketonuria), and those who were unable to complete the study were excluded from the study. None of the participants were reported being vegan.

The subjects were chosen using multistage random sampling, where sub-districts in Depok City were randomly chosen, then continue the randomization into villages level, high school level, and classroom level. Female students from the chosen class were the subjects.

\section{Instruments}

Instruments used to collect the data for this study were 1) structured questionnaire with informed consent for parents or guardian and permission form for students to obtain general characteristics of participants; 2) $24 \mathrm{Hr}$ recall form to obtain 3-day $24 \mathrm{hr}$ recall 1 weekend 2 weekdays dietary intake data; 3 ) Food Photograph Book “Buku Foto Makanan” from Total Diet Survey of Indonesia 2013 by The Ministry of Health to help estimate the portion during $24 \mathrm{hr}$ recall interview; 4) SECA ${ }^{\circledR} 876$ scale to measure participants' weight, and; 5) Shorr board to measure participants' height.

\section{Procedures}

Ethical clearance from the Ethical Committee of Faculty of Medicine, Universitas Indonesia number 999/UN2.F1/ETIK/VIII/2018 and permission letter from local government number 668/AF.1/31/$1.862 .9 / 2018$ were obtained before the study began. The data collection procedure started with delivering informed consent to participants and their respective parents or guardian after an explanation about the study. In the case where the subject's parent was not physically available to sign the form before data collection begins, the school teacher in charge of coordinating the study was appointed as the guardian and can give consent for the subject. 
Data collection was conducted on sample population with interview using the structured questionnaire, continued with 3 -day non-consecutive $24 \mathrm{hr}$ recall 1 weekend 2 weekdays and followed by anthropometric measurement of body weight and height.

\section{Data analysis}

Data was analyzed using IBM SPSS Statistics 20. General characteristics of the participants were presented in numbers and percentages. Descriptive statistics of macronutrient intake were expressed as median (min-max) and as proportions to total energy intake. Spearman's correlation was used to determine if there were relationships between protein and iron intake with participants' general characteristics. The level of significance was set at $p<0.05$.

\section{Results}

\section{General characteristics}

Among eight schools chosen to participate, one school refused to participate. Among 3 public schools and 4 private schools that agreed to participate, a total of 211 participants fit the inclusion criteria and agreed to participate in this study. Among all participants, 55\% attended public school, $50.7 \%$ were in grade 10 , and $57.8 \%$ were in the Natural Science program. The average first menstruation age of all participants was $12.2 \pm 1$ years old, with the earliest menstruation experienced at nine years old and the latest at fifteen years old.

Among participants, 73\% had normal BMI, 0.9\% were very thin, $4.3 \%$ were thin, $15.2 \%$ were overweight, and $6.6 \%$ were obese. Based on the calculation of Height-for-Age, $5.2 \%$ of participants were stunted.

Dietary intake was measured using 3 days nonconsecutive $24 \mathrm{Hr}$ recall interview with one weekend and two weekdays. The median daily energy intake was 1185.8 (497.1-2861.5) kcal. After comparing with their energy requirement, only $2.8 \%$ of the population have adequate energy intake. Using the Goldberg cut-off ratio $\left(\mathrm{EI}_{\mathrm{rep}} / \mathrm{BMR}_{\mathrm{est}}\right)$ of $<1.01$ for a 3 -day $24 \mathrm{Hr}$ recall, this study found that $64.5 \%$ of participants were underreporting their energy intake.
Table 2 showed that the carbohydrate intake in this population was at the lower end of the recommended percentage of carbohydrate to total energy intake. Fat intake was slightly higher than the recommended percentage of fat to total energy intake. In this population, $59.2 \%$ had fat intake more than recommended percentage of total energy intake. Protein intake was within the recommended percentage of protein to total protein intake. Fiber intake was low since it is recommended to consume at least $25 \mathrm{~g}$ of fiber per $2000 \mathrm{kcal}$ consumed daily.

The recommended protein intake to fulfill maintenance and growth for adolescent girls age 1518 years was $0.84 \mathrm{~g} / \mathrm{kg}$ body weight/day. In this study, it was found that $59.7 \%$ of participants have inadequate protein intake. In this population, calories from protein contributed to $12.8 \%$ of total energy intake.

Grains and cereals group (30\%) was the highest source of total protein intake in this population, followed by white meat and its products $(21.6 \%)$, egg and its products $(12.1 \%)$, soy and its products $(9 \%)$, red meat and its products $(7.8 \%)$, aquatic meat and its products $(7.5 \%)$, milk and its products $(6.7 \%)$, vegetables $(1.7 \%)$, nuts and seeds $(1.4 \%)$, roots and tubers $(1.2 \%)$, and fruits $(1 \%)$.

Participants obtain their protein almost equally from both animal (55.7\%) and plant (44.3\%) sources. Protein intake from the animal source was mostly obtained from white meat and its products $(38.2 \%)$, followed by the egg and its products $(22 \%)$, red meat and its products $(14.4 \%)$, aquatic meat and its products (13.6\%), and milk and its products $(11.8 \%)$ consecutively. Protein intake from plant source in this population was mostly obtained from grains and cereals $(69.8 \%)$, followed by soy $(18.6 \%)$, vegetables $(3.9 \%)$, nuts and seeds $(3 \%)$, roots and tubers $(2.6 \%)$, and fruits $(2.1 \%)$ consecutively.

Median iron intake in this population was 4.3 mg/day. Using MSM (Multiple Source Method) probability approach methods with $10 \%$ iron bioavailability for diets rich in cereals but including sources of vitamin $\mathrm{C}$, the prevalence of iron intake inadequacy in this population was $98.6 \%$.

In this population, only one participant $(0.5 \%)$ reported consuming 2 iron supplementation tablets per day. Two participants $(0.9 \%)$ reported consuming 1 iron supplementation tablet per week. 
The iron supplementation tablets consumed by participants were purchased from a drugstore and the brand they consumed contains iron equal to 30 mg elemental iron per tablet.

In this study, protein intake was not correlated with age $(r=0.059, p=0.393, \mathrm{~N}=211)$, father's education ( $r=0.069, p=0.333, \mathrm{~N}=201)$, mother's education ( $r=0.082, p=0.245, \mathrm{~N}=202)$ and number of household member $(r=-0.062, p=0.366, \mathrm{~N}=211)$. Iron intake was not correlated with age $(r=0.128$, $p=0.063, \mathrm{~N}=211)$, father's education $(r=0.021$, $p=0.769, \mathrm{~N}=201)$, mother's education $(r=0.003$, $p=0.966, \mathrm{~N}=202$ ), and number of household member $(r=-0.034, p=0.627, \mathrm{~N}=211)$.

\section{Discussion}

This study examined the nutrient intake of adolescent girls attending schools in an urban area of Indonesia. This population had inadequate intakes of energy $(97.2 \%)$, protein $(59.7 \%)$, and iron $(98.6 \%)$. However, intake of fat was higher than recommended in $59.2 \%$ of participants.

This population tends to have a higher BMI compared to RISKESDAS 2018 data for adolescent girls age 13-15 years and 16-18 years in West Java Province and nationally and among those living in cities $^{6}$. This population has a slightly lower prevalence of thin and very thin girls and a slightly higher prevalence of overweight and obese girls compared to the RISKESDAS 2018 data. ${ }^{6}$

Looking at the overall energy intake, it was found that only $2.8 \%$ of the population have adequate energy intake and $64.5 \%$ of participants were underreporting their energy intake. The average energy intake in this population itself $(1241 \mathrm{kcal})$ was lower than the national energy intake in Indonesian cities at $2108.52 \mathrm{kcal}$ and specifically West Java at $2173.59 \mathrm{kcal}$, so it was predictable to also have low protein intake. $^{7}$

The under-reporting of energy intake was likely due to the under-reporting of energy-source foods. In our study, we used food photographs to estimate portion size and studies have shown that pictures may lead to under-estimated portion as compared to weighing. A study by Valanou et al (2017) found that food pictures may not be appropriate to quantify the intake of amorphous solid foods (i.e pies and pastry fillings) and liquid or semi-liquid foods (i.e porridges $)^{8}$. On the other hand, under-reporting of energy from fat is unlikely to cause energy underreporting since we have taken into account fat absorption during dietary data entry.

Another explanation for the high number of under-reporting is the possibility that the cut-off used in this study might be inappropriate for this population. One of the limitations of the Goldberg cut-off is that it is only appropriate for individuals who are in energy balance. Therefore, they may not be useful for growing children or adults who are dieting to lose weight. ${ }^{9}$

In this population, more than half of the participants had fat intake contribution to total energy that was higher than recommended. Among the required $30 \%$ of fat contribution to total energy intake, it needs to consist of $7-10 \%$ of saturated fatty acids, $7-8 \%$ of polyunsaturated fatty acids, $10-15 \%$ of single unsaturated fatty acids, and intakes of trans fatty acids must be restricted ${ }^{11}$. Long term high-fat diet might result in alteration of insulin function and obesity. Obese adolescents also tend to stay obese through adulthood. Therefore, fat needs to be consumed within the recommended limit. ${ }^{12,13}$

The average protein intake in this population was around $40.3 \mathrm{~g}$ which was lower than the national protein intake in Indonesian cities at $64.09 \mathrm{~g}^{7}$. There were only $40.3 \%$ of participants with adequate intake, which was also lower than the national protein adequacy in cities $(64.09 \mathrm{~g})$ where all were reported to have adequate intake. ${ }^{7}$ Despite the low adequacy, the average protein intake $(40.3 \mathrm{~g})$ was not far from the average protein requirement $(43.5 \mathrm{~g})$ and animal protein contributed more to the total protein intake in this population.

Adequate protein intake especially of the animal source is important for growth and immunity especially for females due to its micronutrient content that is needed during menstruation and pregnancy. ${ }^{2,14}$ Inadequate protein during the adolescent period might put them at risk in later stages of life. $^{2}$

Dietary fiber intake in this population was lower than recommended. Fulfilling fiber intake to a recommended amount is important in the era where adolescent obesity and chronic diseases keep increasing. However, an excessively high-fiber diet may inhibit micronutrient absorption like iron and can also cause inadequate energy intake, therefore 
those with very poor diets with foods of low digestibility need to pay attention to their fiber intake. ${ }^{10}$

In this study, only $1.4 \%$ of this population have adequate iron intake. Adolescent girls are at risk for the development of iron deficiency anemia due to the high demand for iron during this period, the frequent losses during menstruation, diseaseinduced malabsorption, and possibly pregnancy ${ }^{15}$. A similar issue about iron was found in Cambodia where iron was the problem nutrient among adolescent girls aged 15 to 18 years, along with other animal-related nutrients like calcium, vitamin $\mathrm{B}_{2}$, folate, and vitamin A. ${ }^{16}$ A study among adolescent girls age 15-18 years in Malang, East Java found that iron and calcium were absolute problem nutrients in the population, ${ }^{17}$ indicating the problem that adolescent girls tend to have with iron.

In Indonesia, one of the government's programs to improve anemia was to distribute iron supplementation tablets to female students. Each student receives 52 iron supplementation tablets to be consumed every week for a year. According to RISKESDAS 2018, the majority $(77.6 \%)$ of adolescents age 16-18 years old received their iron supplementation tablets from school. ${ }^{6}$ In contrast to that, in this population, only 3 participants $(1.4 \%)$ reported consuming iron supplementation tablets, and all of them were purchased from the drugstore. Among these participants, only the participant who consumed iron supplementation tablets daily had adequate iron intake. This low rate of compliance might be due to the data collection method where iron intake data was obtained from 3-day $24 \mathrm{Hr}$ recall. Hence, complete history of iron supplementation tablets consumption and source during the past year was not assessed.

Adolescent girls with inadequate iron intake may add further burden to the risk of iron deficiency anemia. Iron deficiency may lead to growth disturbance, decreased cognitive performance, depressed immune function, and increased risk of pregnancy complication. ${ }^{18}$

Adolescents who become pregnant at this period or in the future are even at greater risk of various complications since they must compete with their fetus for nutrients and raising the infant's risk of low birth weight and early death. In Indonesia, pregnant females age 15-24 years had the highest prevalence of anemia (84.6\%) compared to other groups. ${ }^{6}$ Therefore, it is important to improve protein and iron intake and promote better eating habits among adolescent girls to reach optimal growth, improve cognitive performance, and prevent health risks in the future. ${ }^{2}$

In this study, protein and iron intake were not correlated with age, father's education, mother's education, and the number of household members. Economic status was not assessed in this study.

Protein foods, particularly of animal that is also rich in heme iron, are often linked to socioeconomic status. But regardless of income, Parents with better education tend to be able to provide more nutritious foods due to their ability to choose foods with good nutritional value. In terms of the number of household members, greater family size might decrease the food intake per capita in general, but in some situations, increasing family size itself may indicate higher socioeconomic status. In addition, instead of a total household member, dependency ratio plays a bigger role in determining food intake. $^{18}$

\section{Strengths and limitations}

This study used 3-day nonconsecutive 1 weekend 2 weekdays $24 \mathrm{Hr}$ recall data which better reflect usual intake. Fat intake was well estimated due to the inclusion of fat absorption during data entry.

However, dietary intake data needs to be analyzed with caution due to the under-reporting of energy intake that was detected in more than $50 \%$ of the intake data. Thus, this is the limitation of this study

\section{Conclusions}

Due to the low adequacy of protein and iron, these adolescent girls might be at risk for iron deficiency and anemia. Inadequate protein and iron intake are worrying particularly among female adolescents due to the demand for rapid growth during puberty and the loss of blood experienced during menstruation. Further studies on the compliance of iron supplementation and factors related to protein and iron intake are needed to help formulate an accurate intervention program. 


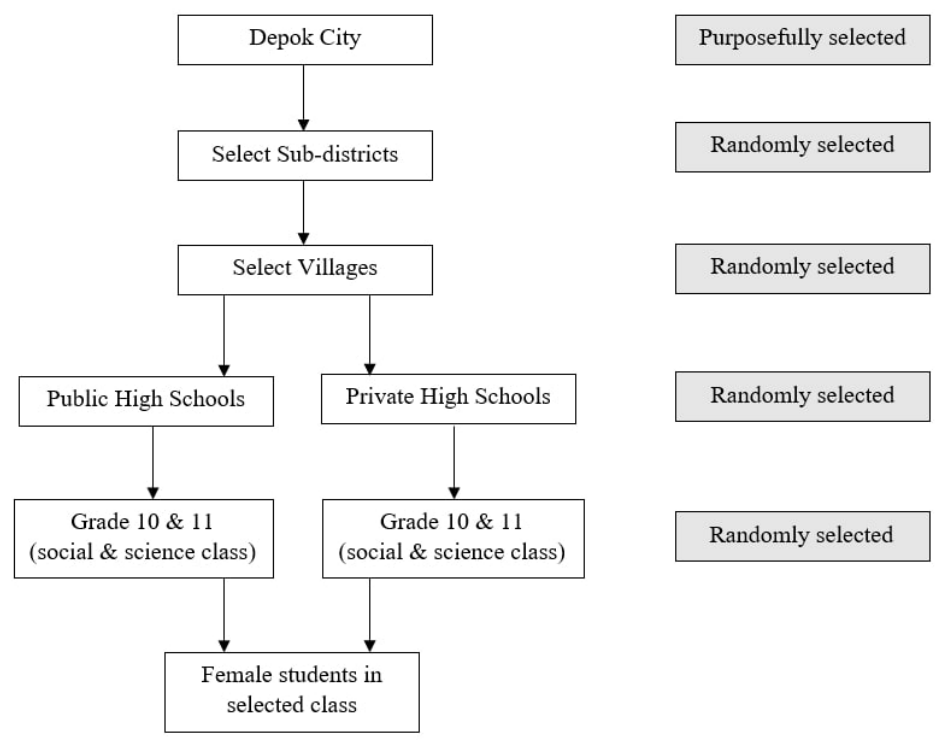

Figure 1. Sampling procedure

Table 1. General characteristics of the participants

\begin{tabular}{lccc}
\hline \multicolumn{1}{c}{ Characteristics } & $\mathbf{n}$ & $\mathbf{\%}$ & $\mathbf{N}$ \\
\hline Age & 130 & 61.6 & \\
15 & 77 & 36.5 & \\
16 & 4 & 1.9 & \\
17 & & & \\
Father's Education & 1 & 0.5 & \\
$\quad$ No education & 28 & 13.9 & \\
$\leq 9$ years & 172 & 85.6 & 202 \\
$\quad>9$ years & 0 & 0 & \\
Mother's Education & 37 & 18.3 & 210 \\
$\quad$ No education & 165 & 81.7 & \\
$\quad \leq 9$ years & & & \\
$\quad>9$ years & 4 & 1.9 & 206 \\
Father's Occupation & 206 & 98 & \\
$\quad$ Not Working & & & \\
$\quad$ Working & 12 & 5.8 & 211 \\
Mother's Occupation & 194 & 94.2 & \\
$\quad$ Not Working & & 53.1 & \\
$\quad$ Working & 112 & 46.9 & \\
Number of household member & 99 &
\end{tabular}


Table 2. Macronutrient intake of participants $(\mathrm{N}=211)$

\begin{tabular}{lcccc}
\hline Macronutrient & Median (g) & Min-Max (g) & $\begin{array}{c}\text { \% contribution to energy } \\
\text { intake }\end{array}$ & $\begin{array}{c}\text { Recommended \% to total } \\
\text { energy intake }\end{array}$ \\
\hline Carbohydrate & 166.3 & $60.9-375$ & 55 & $55-70 \%$ \\
Fat & 41.2 & $13.3-121$ & 30.6 & $15-30 \%$ \\
Protein & 38.6 & $12.7-84.2$ & 12.8 & $10-15 \%$ \\
Fiber & 4.9 & $1.3-63.1$ & 1.6 & $5 \%$ \\
\hline
\end{tabular}

\section{Conflict of Interest}

Authors declared no conflict of interest regarding this article.

\section{Acknowledgment}

We would like to thank Universitas Indonesia and RSUI Depok for providing the necessary funding to conduct this study. We would like to also thank the participants, teachers, and parents for giving us the opportunity to conduct the research.

\section{Open Access}

This article is distributed under the terms of the Creative Commons Attribution 4.0 International Licence (http://creativecommons.org/licenses/by/4.0/), which permits unrestricted use, distribution, and reproduction in any medium, provided you give appropriate credit to the original author(s) and the source, provide a link to the Creative Commons license, and indicate if changes were made.

\section{References}

1. Stang J, Story M. Guidelines for Adolescent Nutrition Services. Chapter 1: Adolescent Growth and Development. 2005. http://www.epi.umn.edu/let/pubs/adol book.shtm

2. Ransom EI, Elder LK. 2003. Nutrition of Women and Adolescent Girls: Why It Matters. 2003. Population Reference Bureau. http://www.prb.org/Publications/Articles/2003/Nutritio nofWomenandAdolescentGirlsWhyItMatters.aspx

3. Indonesian Ministry of Health. RISKESDAS 2018. Kemenkes, Jakarta. https://www.kemkes.go.id/resources/download/infoterkini/hasil-riskesdas-2018.pdf

4. Sumarlan ES, Windiastuti E, Gunardi H. 2018. Iron Status, Prevalence and Risk Factors of Iron Deficiency
Anemia Among 12- to 15-Year-Old Adolescent Girls from Different Socioeconomic Status in Indonesia. Makara J. Health Res., 2018, 22(1): 46-52 DOI: 10.7454/msk.v22i1.8078

5. National Coordinating Committee on Food and Nutrition (NCCFN) Ministry of Health Malaysia. 2017. Recommended Nutrient Intakes for Malaysia. https://expert.taylors.edu.my/file/rems/publication/107 1263033 1.pdf

6. Badan Pusat Statistik, 2020. Konsumsi Kalori dan Protein Penduduk Indonesia dan Provinsi. Maret 2020. Badan Pusat Statistik https://www.bps.go.id/publication/2020/11/02/dde28c6 757a5e3ef908f5452/konsumsi-kalori-dan-proteinpenduduk-indonesia-dan-provinsi-maret-2020.html

7. Valanou, E., Naska, A., Barbouni, A., Katsoulis, M., Peppa, E., Vidalis, P., \& Trichopoulou, A. 2018. Evaluation of food photographs assessing the dietary intake of children up to 10 years old. Public Health Nutrition, 21(5), 888-895 doi:10.1017/S136898001700335427.

8. Fahmida U, Dillon D. H. S. 2011. Nutritional Assessment: Handbook ( $2^{\text {nd }}$ ed.). Southeast Asian Ministers of Education Organization Regional Centre for Food and Nutrition University of Indonesia (SEAMEO RECFON UI)

9. Applegate, L., Ozpınar, H. (2011). Nutrition and Diet (1st ed.). İstanbul: Istanbul Medical Publishing.

10. Praditasari J. A., Sumarmi S. 2018. Asupan Lemak, Aktivitas Fisik, dan Kegemukan pada Remaja Putri di SMP Bina Insani Surabaya. Media Gizi Indonesia, Vol. 13, No. 2 Juli-Desember 2018: hlm. 117-122. DOI: 10.20473/mgi.v13i2.117-122

11. Sargowo D, Andarini S. 2011. The Relationship between Food Intake and Adolescent Metabolic Syndrome. J Kardiol Indones. 2011;32:14-23. DOI: https://doi.org/10.30701/ijc.v32i1.116

12. Giovannini M, Agostoni C, Gianni M, Bernardo L, Riva E, 2000. Adolescence: macronutrient needs. European Journal of Clinical Nutrition 54 Suppl 1, S7-S10. DOI: $10.1038 /$ sj.ejcn.1600977

13. Edward C.A., Xie C, Garcia A.L. 2015. Dietary Fibre and Health in Children and Adolescents. Conference on 'Carbohydrates in health: friends or foes' Plenary Lecture 4. Proceedings of the Nutrition Society (2015), 74, 292-302. doi:10.1017/S0029665115002335

14. Carrard, Kruseman M, Marques-Vidal P. Desire to lose 
weight, dietary intake and psychological correlates among middle-aged and older women. The CoLaus Study. Preventive Medicine 113 (2018) 41-50. DOI:10.1016/j.ypmed.2018.05.011

15. Ferguson EL, Watson L, Chea M, et al. Realistic foodbased approaches alone may not ensure dietary adequacy for women and young children in South East Asia. Matern Child Health J. 2019; 23(Suppl 1):55-66. DOI: $10.1007 / \mathrm{s} 10995-018-2638-3$

16. Sreymom O, Witjaksono F, Mustafa A, Setyobudi SI, Fahmida U. 2019. Problem Nutrients in Adolescent Girls With Anemia Versus Nonanemic Adolescent Girls and the Optimized Food-Based Recommendations to Meet Adequacy of These Nutrients in Adolescent School Girls in East Java, Indonesia. Food and Nutrition Bulletin 2019, 40(3) 295-307 https://doi.org/10.1177/0379572119851326

17. Hermoso M, Vucic V, Vollhardt C, Arsic A, RomanViñas B, Iglesia-Altaba I, Gurinovic M, Koletzko B: The Effect of Iron on Cognitive Development and Function in Infants, Children and Adolescents: A Systematic Review. Ann Nutr Metab 2011;59:154-165. DOI: $10.1159 / 000334490$

18. Chaudhury RH. 1989. Determinants of Nutrient Adequacy in A Rural Area of Bangladesh. Food and Nutrition Bulletin, vol. 8, no. 4 1986, The United Nations University. https://journals.sagepub.com/doi/pdf/10.1177/1564826 58600800413 